\title{
Impact of triticale malt application on physiochemical composition and profile of volatile compounds in beer
}

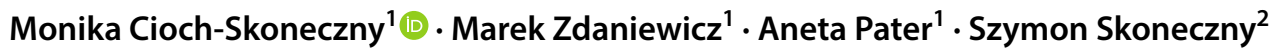

Received: 28 October 2018 / Revised: 16 April 2019 / Accepted: 27 April 2019 / Published online: 11 May 2019

(c) The Author(s) 2019

\begin{abstract}
In brewing industry, adjuncts may replace malt, but they may also represent a raw material for brewing beer demonstrating different, specific organoleptic qualities. Triticale grain may give good quality malts, characterised by high extraction capacity, high diastatic power and short saccharification time. The purpose of the research was to determine the impact of triticale malt application on physiochemical composition and profile of volatile compounds in beer. In fermented wort, the content of ethyl alcohol, extract, sugars, general acidity, colour, haze, free aminonitrogen and volatile compound profile (GC-SPME) was determined. Beers produced from the triticale malt or with use of a malt mixture were characterised by higher acidity and lower ethyl acetate butanol and isoamyl alcohol. The worts analysed in the process demonstrated parameters normative for pale malts. The triticale malt may be an alternative for barley malt.
\end{abstract}

Keywords Triticale $\cdot$ Wort $\cdot$ Beer $\cdot$ Volatile compounds

\section{Introduction}

Except for traditionally used barley malt, many raw materials which represent a source of starch are used in the brewing industry. The barley malt is often replaced with other, less expensive sources of starch or, directly, with fermenting sugars. These are mainly: corn grits, sorgo, oats and other grains available locally in different parts of the world as well as glucose syrup or saccharose. Wheat ranks as one of the most popular grains used in the beer brewing industry, used both as a taste-enriching adjunct (in insignificant quantities, e.g., $10-15 \%$ of the raw material input) as well as the main component (above $55 \%$ of the input), in case of wheat beers. From the perspective of the Polish economy, a search for alternative raw materials should focus on a potential use of the local varieties of triticale. It is a cross-breed of wheat and rye, with a long list of advantages, thus creating a vast array of opportunities for its commercial use. It is economically

Monika Cioch-Skoneczny

monika.cioch@urk.edu.pl

1 Department of Fermentation Technology and Technical Microbiology, University of Agriculture in Krakow, Kraków, Poland

2 Department of Chemical and Process Engineering, Cracow University of Technology, Kraków, Poland attractive to replace malt with non-malt raw materials [1]. The Polish beer market is dominated by the low fermentation beers whose similarity in terms of their taste and quality is increasing. Malt substitutes used in the brewing process give different organoleptic qualities to the beer, e.g., lighter colour or more delicate taste.

Similarly to barley, the dominant component of triticale grain are saccharides, including starch (50-85\%) and the latter is co-decisive about the technological and nutritional value and the energy value in particular. High susceptibility to germination and short after-harvest rest indicate high activity of amylolytic enzymes. Both non-malted triticale grain as well as triticale malt is characterised by high diastatic power, short saccharification time and high extraction capacity [2]. Disadvantages of malts related to impeded filtration, viscosity and haze may be removed by adding enzymatic preparations decomposing non-starch hydrocarbons, mainly pentoses, in the process of mashing. The production of lambic beer made from barley malt with a $35 \%$ adjunct of non-malted wheat grain indicates that replacement of barley with another ram material, combined with a specifically formulated brewing technology may have a positive result.

Alternative raw materials used to replace traditional malt not only bring economic benefits, but also serve to produce beer with completely different organoleptic properties. However, they should be used in a way that in addition to 
lowering production costs leads to maintaining or improving the quality of the finished drink.

The purpose of the research was to analyse in terms of all aspects a potential application of triticale grain as an alternative raw material for the brewing industry. The impact of triticale malt application on the physiochemical composition and profile of volatile beer compounds.

\section{Materials and methods}

\section{Materials}

The experimental material was barley malt and triticale grain of Remiko variety, originating from the 2016 vegetation season. Triticale malting was carried out under laboratory conditions at the Department of Fermentation Technology and Technical Microbiology of Agricultural University in Krakow. Soil samples with a mass of $200 \mathrm{~g}$ were prepared for soaking. Soaking and malting of the grain were carried out in plastic containers in a thermostatic cabinet that kept the temperature between 9 and $10^{\circ} \mathrm{C}$. The soaking cycle lasted $45 \mathrm{~h}$. The grain was kept in water and in the air atmosphere according to the following scheme ( $\mathrm{w}$ - water, $\mathrm{p}$-air atmosphere) $8 \mathrm{~h}-\mathrm{w}, 11 \mathrm{~h}-\mathrm{p}, 5 \mathrm{~h}-\mathrm{w}, 8 \mathrm{~h}-\mathrm{p}, 11 \mathrm{~h}-\mathrm{w}$, $5 \mathrm{~h}-\mathrm{p}$. As a result of soaking, the assumed grain moisture content was $46 \%$. Malting time was counted from the end of the soaking cycle and lasted 4 days. Every day the grain was mixed and moisturized with water. After the malting process was completed, the malt samples were dried in a ventilated laboratory oven using the following temperatures: $12 \mathrm{~h}-35{ }^{\circ} \mathrm{C}, 2 \mathrm{~h}-50{ }^{\circ} \mathrm{C}, 2 \mathrm{~h}-60{ }^{\circ} \mathrm{C}, 1.5 \mathrm{~h}-65^{\circ} \mathrm{C}$. The dry malt, after the previous germination on the sieves, was placed in a sealed container.

Lab wort produced from triticale and barley malt served as the research material. 3 types of wort (A, B and C) were prepared for fermentation, using the Congress Mash procedure and malt in different proportions $(1-100 \%$ of triticale malt, $\mathrm{B}-50 \%$ of triticale malt $+50 \%$ of barley malt, $\mathrm{C}-$ barley malt).

The temperature was maintained at $45^{\circ} \mathrm{C}$ for $40 \mathrm{~min}$, then heated to $70{ }^{\circ} \mathrm{C}$ at a rate of $1{ }^{\circ} \mathrm{C} / 1 \mathrm{~min}$. After obtaining the required temperature, $100 \mathrm{~cm}^{3}$ of distilled water was added to the mush tubs. The temperature was maintained at $70{ }^{\circ} \mathrm{C}$ for $60 \mathrm{~min}$. Then an iodine test was carried out to determine the degree of saccharification of the starch in the mash. Subsequently, the mash was cooled and filtered through a filter paper. To ensure high clarity, the first portions of the filtrate were recycled. The clear worts were subjected to a cooking process in round bottom flasks which were heated to the boiling point in the heating bowls. The $200 \mathrm{~cm}^{3}$ wort was boiled for $1 \mathrm{~h}$ with $0.2 \mathrm{~g}$ of Amarillo hops. The resulting turbidity was removed by adding diatomaceous earth $(0.1 \mathrm{~g})$ and filtering the worts through a filter paper. The following worts were then evaluated (extract content, filtration time, colour, clarity, IBU, free amino nitrogen, acidity).

The fermentation process was conducted in $500 \mathrm{ml}$ conical flasks. $200 \mathrm{ml}$ of wort with approx. $8.5^{\circ} \mathrm{Blg}$ extract was poured into each flask, next $0.5 \mathrm{~g} \mathrm{s.s} / 1$ of Saccharomyces cerevisiae (Saflager W34/70) was added to each flask. The flasks were placed in a refrigerator in the temperature of approximately $14{ }^{\circ} \mathrm{C}$ and kept there until the fermentation process ended. Intensity of the fermentation process was determined on the basis of a loss in the mass of the samples, weighted every $24 \mathrm{~h}$ with $0.01 \mathrm{~g}$ accuracy. The process was completed at the moment of achieving daily weight losses below $0.01 \mathrm{~g} / \mathrm{l}$.

The results of three parallel repetitions were presented as a percentage drop in the mass of the fermentation medium.

In the fermented wort, the content of ethyl alcohol (Alcolyzer, Anton Paar), extract, sugars, general acidity, colour, haze, free amino nitrogen and volatile compound profile (GC-SPME) was determined.

\section{Methods applied}

The ethyl alcohol content, extract, $\mathrm{pH}$ measurement, calorific value was determined using the automatic wort and beer analyser (Alcolyzer, Anton Paar).

Colour measurement was taken at $430 \mathrm{~nm}$ wave length in $10 \mathrm{~mm}$ thick cuvettes, according to the photometric method according to Analytica EBC (1987).

Beer haze was determined using Eutech Instruments Turbidimeter TN-100.

Free amino nitrogen (FAN) was spectrophotometrically determined with a ninhydrin reagent.

The samples were diluted in distilled water and transferred $2 \mathrm{ml}$ into glass tubes using a pipette. Then $1 \mathrm{~cm}^{3}$ of a ninhydrin coloured reagent was added and boiled for $16 \mathrm{~min}$ in a boiling water bath. After cooling, $5 \mathrm{~cm}^{3}$ of the dilution reagent was introduced into the tubes, mixed and the absorbance measured at $575 \mathrm{~nm}$. As a standard sample, a solution of glycine containing $2 \mathrm{mg} / \mathrm{dm}^{3}$ of nitrogen was used. The result was calculated using the formulas for estimating protein content and determining the amount of nitrogen in the sample.

Nitrogen content $=(($ sample absorbance $\times 2 \mathrm{mg}$ nitrogen $) /$ absorbance of the standard solution) $\times 50$.

Volatile compounds were analysed with HP 5890 Series II gas chromatograph with INNOVAX capillary column $(30 \mathrm{~m} \times 0.53 \mathrm{~mm}, 1.0 \mu \mathrm{m})$. To a $15 \mathrm{~cm}^{3}, 2 \mathrm{~cm}^{3}$ of the analysed beer were added, together with a pattern (4-methyl-2-pentanol-higher alcohols, ethyl nonanoateesters) with concentration at $50 \mathrm{mg} / \mathrm{dm}^{3}$ and $0.9 \mathrm{~g} \mathrm{NaCl}$. The phials were capped with a cap with a Teflon seal and placed in an incubator at $40{ }^{\circ} \mathrm{C}$ and the content was stirred 
with a magnetic bar stirrer. In the episurface layer, SPME fibre was inserted for $35 \mathrm{~min}$ (PDMS, $100 \mu \mathrm{m}$, Supelco). Adsorbed analytes were desorbed in the gas chromatograph dispenser for $3 \mathrm{~min}$. Next, model curves were made-the function of dependence of a compound concentration on the peak surface field for the analysed chemical components (diacetyl, propanol, butanol, isoamyl alcohol, phenylethanol, ethyl acetate, isobutyl acetate, 2-phenylethyl acetate).

\section{Statistical analysis}

Results presented in the paper were the means of three independent repetitions with determination of the standard deviation. The data were analysed with the variance analysis (ANOVA) to establish the significance of tested parameters. Statistically significant differences between the means were verified with Duncan's set using Statistica 10 statistical software (StatSoft Polska, Kraków).

\section{Results and discussion}

The characteristics of the parameters of worts obtained are presented in Table 1.

The speed of wort filtration in the beer production process is significantly conditioned by the type of starch raw material used, in the process of mashing. In the process of obtaining malt mash from malt barley or barley triticale with the addition of unmalted triticale grains, the products of incomplete enzymatic hydrolysis of pentosans are regarded as the main cause of difficult filtration of worts and over-standard viscosity of worts. According to previous research, regardless of the variety and time of triticale malting, all triticale worts are characterized by difficult filtration and too much viscosity.

This problem can be solved with the addition of enzymatic preparations that hydrolyze mainly pentozanes [3]. The disadvantage of this method is that they pass into the wort, causing the organoleptic values of the beer to be reduced. It should be noted that worts with triticale were characterized by a shorter filtration time in relation to the barley wort (Table 1).

The result of the filtration should be a clear barley wort, which is obtained by means of a husk, forming a bed at the bottom of the filtration vat. Literature studies show that the addition of $25 \%$ triticale decreases the viscosity by $19 \%$ and reduces the mash filtration capacity by over $10 \%[1,3]$. Replacement of a part with triticale malt has no significant effect on wort clarity. However, the use of only triticale malt does not result in the appearance of turbidity (Table 1).

The wort extract produced as a result of mashing barley malt was comparable to that used for buckwheat malt (Table 1).

It was shown that the addition of triticale malt to the filling significantly increases the colour of the wort (5.53 ECB) (Table 1). It is worth noting that the colour of the analysed wort does not give full information about the expected colour of the finished beer, and only can indicate which type

Table 1 Comparison of the characteristics of triticale worts, barley worts, barley and triticale worts

\begin{tabular}{|c|c|c|c|c|c|c|c|c|c|}
\hline \multirow[t]{2}{*}{ Wort } & $\begin{array}{l}\text { Time of } \\
\text { saccharifi- } \\
\text { cation }\end{array}$ & $\begin{array}{l}\text { Time of } \\
\text { filtration }\end{array}$ & Colour & $\mathrm{PH}$ & IBU & Extract & Turbidity & $\begin{array}{l}\text { Titratable } \\
\text { acidity }\end{array}$ & $\begin{array}{l}\text { Nitrogen } \\
\text { compounds }\end{array}$ \\
\hline & Min & Min & EBC & & & ${ }^{\circ} \mathrm{P}$ & NTU & $\begin{array}{l}\mathrm{Cm}^{3} 1 \mathrm{M} \\
\mathrm{NaOH} / 100 \mathrm{~cm}^{3} \\
\text { beer }\end{array}$ & $\mathrm{mg} / \mathrm{l}$ \\
\hline \multicolumn{10}{|l|}{ A } \\
\hline $\begin{array}{l}\text { Triticale malt } \\
\quad(100 \%)\end{array}$ & $\begin{array}{l}12.00^{\mathrm{a}} \\
( \pm 0.00)\end{array}$ & $\begin{array}{l}36.50^{\mathrm{a}} \\
\quad( \pm 1.00)\end{array}$ & $\begin{array}{l}6.60^{\mathrm{a}} \\
\quad( \pm 0.00)\end{array}$ & $\begin{array}{l}6.24^{\mathrm{a}} \\
\quad( \pm 0.01)\end{array}$ & $\begin{array}{l}83.00^{\mathrm{a}} \\
\quad( \pm 1.00)\end{array}$ & $\begin{array}{l}8.55^{\mathrm{a}} \\
\quad( \pm 0.06)\end{array}$ & $\begin{array}{l}37.95^{\mathrm{a}} \\
\quad( \pm 1.35)\end{array}$ & $0.60^{\mathrm{a}}( \pm 0.05)$ & $\begin{array}{l}170.00^{c} \\
( \pm 2.50)\end{array}$ \\
\hline \multicolumn{10}{|l|}{ B } \\
\hline $\begin{array}{l}50 \% \text { of } \\
\text { triticale } \\
\text { malt }+50 \% \\
\text { of barley } \\
\text { malt }\end{array}$ & $\begin{array}{l}5.50^{\mathrm{b}} \\
\quad( \pm 0.00)\end{array}$ & $\begin{array}{l}42.50^{\mathrm{a}} \\
\quad( \pm 1.14)\end{array}$ & $\begin{array}{l}5.53^{\mathrm{b}} \\
\quad( \pm 0.26)\end{array}$ & $\begin{array}{l}6.18^{\mathrm{b}} \\
( \pm 0.02)\end{array}$ & $\begin{array}{l}81.00^{\mathrm{a}} \\
\quad( \pm 1.00)\end{array}$ & $\begin{array}{l}8.53^{\mathrm{b}} \\
\quad( \pm 0.21)\end{array}$ & $\begin{array}{l}45.23^{\mathrm{a}} \\
\quad( \pm 0.05)\end{array}$ & $0.86^{\mathrm{b}}( \pm 0.01)$ & $\begin{array}{l}185.00^{\mathrm{b}} \\
( \pm 3.20)\end{array}$ \\
\hline \multicolumn{10}{|l|}{$\mathrm{C}$} \\
\hline $\begin{array}{l}\text { Barley malt } \\
(100 \%)\end{array}$ & $\begin{array}{l}3.00^{\mathrm{c}} \\
\quad( \pm 0.58)\end{array}$ & $\begin{array}{l}52.00^{\mathrm{a}} \\
\quad( \pm 4.36)\end{array}$ & $\begin{array}{l}3.85^{\mathrm{b}} \\
\quad( \pm 0.51)\end{array}$ & $\begin{array}{l}6.04^{\mathrm{c}} \\
( \pm 0.01)\end{array}$ & $\begin{array}{l}72.00^{\mathrm{b}} \\
\quad( \pm 1.00)\end{array}$ & $\begin{array}{l}8.50^{\mathrm{c}} \\
\quad( \pm 0.06)\end{array}$ & $\begin{array}{l}44.83^{\mathrm{a}} \\
\quad( \pm 2.87)\end{array}$ & $0.82^{\mathrm{b}}( \pm 0.01)$ & $\begin{array}{l}210.00^{\mathrm{a}} \\
\quad( \pm 4.80)\end{array}$ \\
\hline $\mathrm{Sig}^{1}$ & $* * *$ & $* *$ & $* * *$ & $*$ & ns & $* *$ & $* * *$ & $* *$ & $* *$ \\
\hline
\end{tabular}

$n s$ not significant

${ }^{1}$ Sig.: ***,***-display the significance at $0.5,0.1$ and 0.05 by least significant difference

Values with different letters $(\mathrm{a}-\mathrm{c})$ in the same column are significantly different according to the Duncan test $(\mathrm{p}<0.05)$ 
of malt has been used to obtain it. The wort colour obtained exclusively from barley malt was 3.85 ECB (Table 1).

The $\mathrm{pH}$ value affects the activity of malt enzymes. It also affects the solubility of substances contained in hops, the precipitation of protein compounds and the efficiency of $\alpha$-acid isomerization [4]. The results presented in Table 2 indicate that the proportion of tested raw materials does not cause significant changes in the $\mathrm{pH}$ and acidity of the wort (Table 1).

The content of free amine nitrogen (FAN) in the case of worts obtained from triticale malt is lower $(170 \mathrm{mg} / \mathrm{l})$ in comparison with barley malt $(210 \mathrm{mg} / \mathrm{l})$ (Table 1$)$. The content of free amino acid nitrogen in malt worts informs about the presence of low-molecular nitrogen compounds assimilated by brewer's yeast. The recommended minimum content of free nitrogen compounds in the wort should be approx. $200 \mathrm{mg} / \mathrm{l}$.

Tables 2 and 3 compare some selected features of beers produced in lab conditions from triticale and barley malts in different proportions (A, B, C). 8.5 Blg worts were boiled with Amarillo hops preparation for $60 \mathrm{~min}$. Dry yeast Saflager W34/70 was applied (0.5 g s.s/l).

The primary fermentation was performed at $14{ }^{\circ} \mathrm{C}$ in conical flasks with a glycerine-filled fermentation tube. Beer in flip-topped bottles was stored in a refrigerators (at the temperature ranging from 0 to $4{ }^{\circ} \mathrm{C}$ ) for 2 weeks. The identical recipe was used in the production of barley beers, beers with triticale malt and barley malt and triticale beers. The only variable factor was the share of the triticale malt $(50 \%, 100 \%)$. On the basis of an analysis of the beer, it was found that, in comparison to the beer produced from the barley malt (C), the triticale beers (A) or beers to which the triticale malt was added (B) were characterised by similar values of the real extract (3.58-3.88\% of weights), similar attenuation (1.15-1.21\%) and similar content of ethyl alcohol (2.85-3.12 vol\%) (Table 2).

Figure 1 presents the percentage loss in mass of the fermenting worts. The results of the analysis lead to conclusion that the fermentation process in all samples was similar (A, $\mathrm{B}$ and $\mathrm{C}$ ). The fermentation efficiency reached its maximum efficiency after 4-6 days of the process and continued at a comparable level.

The biggest loss of the extract was observed in the triticale beer (A) of approximately $41 \%$. Beer produced from barley malt (C) and barley malt with triticale malt (B) added to it was characterised by similar loss of extract (Table 2). The bigger loss of the extract is related to a more intensive growth in biomass. Considering the fact that all beer (A, B, C) was inoculated with the same quantity of yeast, the higher growth of the biomass resulted from the increased assimilation of sugars from the wort which may have been determinant for more favourable conditions for cell growth. Such situation was observed in the triticale beer (A) for which the

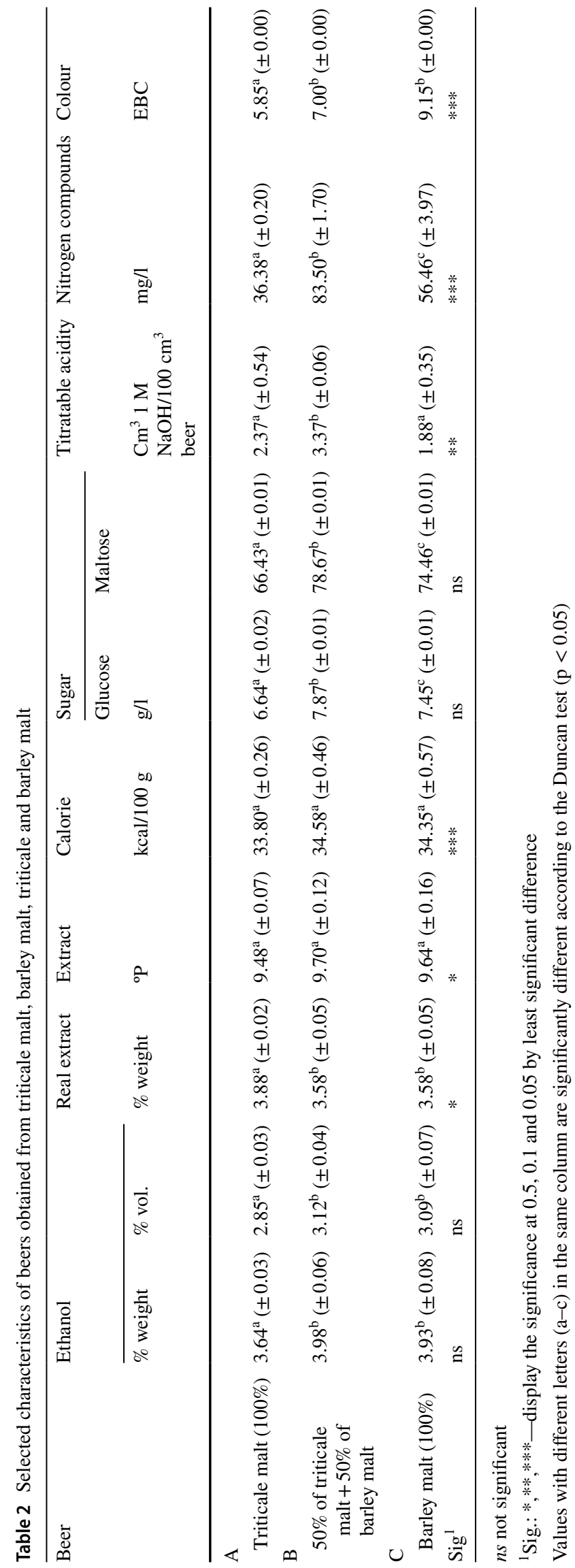


Table 3 Selected volatile components in beers obtained from triticale malt, barley malt, barley and triticale malt

\begin{tabular}{|c|c|c|c|c|c|c|c|}
\hline Beer & $\begin{array}{l}\text { Butanol } \\
\mathrm{mg} / \mathrm{l}\end{array}$ & Isoamyl alcohol & Phenylethanol & Ethyl acetate & Isobutyl acetate & 2-phenylethyl acetate & Diacetyl \\
\hline \multicolumn{8}{|l|}{ A } \\
\hline Triticale malt (100\%) & $2.26^{\mathrm{a}}( \pm 0.52)$ & $89.72^{\mathrm{a}}( \pm 0.75)$ & $35.09^{\mathrm{a}}( \pm 0.00)$ & $49.23^{\mathrm{a}}( \pm 0.05)$ & $2.44^{\mathrm{a}}( \pm 0.00)$ & $4.94^{\mathrm{a}}( \pm 0.14)$ & $>0.05$ \\
\hline \multicolumn{8}{|l|}{ B } \\
\hline $\begin{array}{l}50 \% \text { of triticale } \\
\text { malt }+50 \% \text { of } \\
\text { barley malt }\end{array}$ & $3.05^{\mathrm{b}}( \pm 0.02)$ & $91.45^{\mathrm{b}}( \pm 0.34)$ & $35.10^{\mathrm{b}}( \pm 0.00)$ & $49.78^{\mathrm{ab}}( \pm 0.14)$ & $2.45^{\mathrm{b}}( \pm 0.00)$ & $4.84^{\mathrm{a}}( \pm 0.00)$ & $>0.05$ \\
\hline \multicolumn{8}{|l|}{$\mathrm{C}$} \\
\hline Barley malt (100\%) & $3.32^{\mathrm{b}}( \pm 0.22)$ & $90.54^{\mathrm{ab}}( \pm 0.29)$ & $35.07^{\mathrm{c}}( \pm 0.01)$ & $50.18^{\mathrm{b}}( \pm 0.78)$ & $2.45^{\mathrm{b}}( \pm 0.00)$ & $4.83^{\mathrm{a}}( \pm 0.00)$ & $>0.05$ \\
\hline $\operatorname{Sig}^{1}$ & $* * *$ & $*$ & $*$ & $* * *$ & $*$ & $* * *$ & - \\
\hline
\end{tabular}

$n s$ not significant

${ }^{1}$ Sig.: ***,***_display the significance at $0.5,0.1$ and 0.05 by least significant difference

Values with different letters $(\mathrm{a}-\mathrm{c})$ in the same column are significantly different according to the Duncan test $(\mathrm{p}<0.05)$

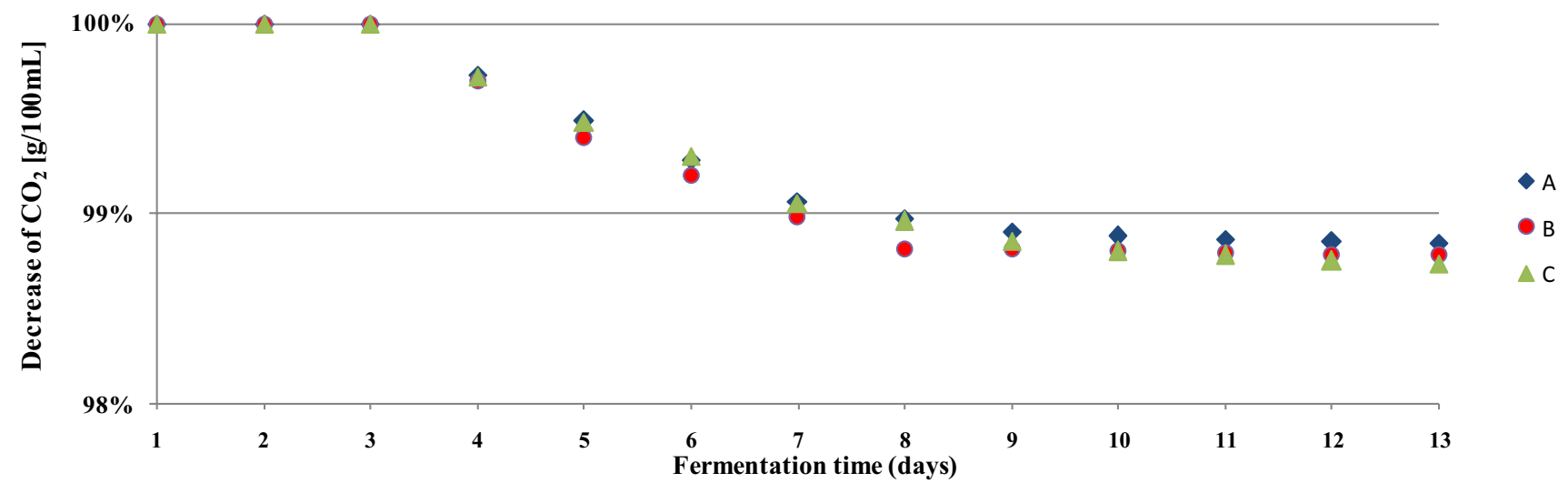

Fig. 1 The fermentation kinetics of worts

lowest level of the reducing sugars was reported $(73.07 \mathrm{~g} / \mathrm{l})$ (Table 2). The date available in the literature indicates that the increased loss of the extract may also result from over foaming the fermenting wort [5]; however, the thesis was excluded in the tests performed.

Free amino nitrogen (FAN) represents a very important nutritious substance for the brewing industry and is the key to keeping yeast cells in the proper conditions during the fermentation process. It is emitted from malt in the mashing process. The age and the quality of malt affect the quantity of FAN in the wort. Its low content in the mash may cause fermentation to stop directly as a result of analyses of yeast cells. FAN concentration is considered a predication ratio for the condition and viability of yeast and efficiency of fermentation, which allows for preserving the quality and stability of beer. In case when material other than barley is issued, e.g., corn, rice, unmalted wheat, honey or refined sugar, malt will not contain an adequate quantity of nutritional substances required for proper development of yeast cells [6]. Furthermore, FAN is reduced by applying a thermal load to the wort in the boiling process as well as by the hopping technique [7]. Low FAN content delays ageing processes and is an important beer stability factor [8]. On the other hand, too high FAN content in the wort may cause a change in taste of beer and microbiological instability caused by growth of microorganisms. Far-reaching decomposition of protein in the mashing process, leading to creation of a large number of aminoacids is undesirable as "empty" tasting beer is the result. In addition, an excessive content of the FAN has an adverse impact on disadvantageous reactions leading an accelerated "ageing" process resultant from development of linear aldehydes, which are characteristic for low organoleptic stability of the stored beer [7]. Beer from triticale malt and barley malt (B) was characterised with the highest content of amine nitrogen $(83.5 \mathrm{mg} / \mathrm{l})$ demonstrating that application of triticale to the production of the beverage was justified (Table 2).

The colour of beer is a resultant of many factors; however, it mainly depends on the method used to mill the raw material and the number of colour compounds introduced to the 
wort [9]. The colour value of the wort obtained from the triticale malt (6.60 EBC) was significantly higher than the colour value of the wort from the barley wort (3.85 EBC) (Table 1). According to the literature, adding material from triticale may be the reason for a darker colour of the wort, recognised as its defect [10].

$\mathrm{pH}$ value has a direct impact on the malt enzyme activity. An appropriate $\mathrm{pH}$ value affects solubility of the substances contained in the hops, precipitation of protein compounds and the efficiency of $\alpha$-acid isomerisation [4]. $\mathrm{pH}$ of the wort from the process was similar and oscillated between 6.04 and 6.24 (Table 1).

In turn, IBU of the wort from the triticale malt (A) and from application of a blend of malts (B) oscillated on a similar level (83 and 81 IBU, respectively) while a lower bitterness (72 IBU) was reported in the control sample (C) (Table 1).

During the process of alcohol fermentation, brewing yeast, apart from ethanol and carbon dioxide, synthesise a broad spectrum of various side products of metabolism. The quantity and quality of released products and indirect metabolites affects the organoleptic properties of finished beer. These components give it a specific and characteristic taste and aroma [11].

Esters represent the largest group of side products occurring in fermented beverages $[12,13]$. Although approximately 60 different esters were discovered in beer, only few of them play an important role in creating its aroma. The group includes, among other: ethyl acetate, isoamyl acetate, isobutyl acetate, ethyl hexanoate and ethyl butyrate. Ester aromas are a group of sweet and fruit aromas produced in beer during the fermentation. In ethyl acetate production the main role is played by alcohol acetyltransferase, whose activity is largely dependent on the synthesis of protein and fermentation temperature. It was demonstrated that the biggest quantity of the component is produced at $20^{\circ} \mathrm{C}$ [13]. In analysed beers, ethyl acetate content remained at a comparable level (49.23-50.18 mg/l) (Table 3). Isobutyl acetate gives a fruity aroma to beers. Its content in the analysed beers was reported at the same level (Table 3). In the majority of beers, ester aromas are not a flow unless they dominate the aroma of the beverage. In some cases, their presence may result from non-observance of appropriate hygienic measures during the production as well as from improper conditions of the fermentation process. Yeast replacement, improvement of conditions of fermentation (yeast produces more esters in beers with a higher extract, at too low oxygenation, stronger fermentation of beer and at a higher temperature) as well as use of different hops varieties or modification of hopping scheme may contribute to eliminating too high concentration of these compounds in the beverage [14]. Note that the final level as well as the qualitative and quantitative composition of esters is determined during maturation.
When beer is stored, its chemical composition may change and the change affects both its taste and its smell. Aromas developing during the ageing are not always described as defects and, in some beer styles (Baltic porter, bock), when in a right concentration, they represent a valid component of their aroma. Examples of aromas developing in the beer ageing process are: acetic aldehyde, almond aldehyde, feline aldehyde, skunk aldehyde, paper aldehyde, spice aldehyde, vanilla aldehyde and skin aldehyde. Acetaldehyde occupies the main position among beer aldehydes (more than 60\%). In some styles, it may have a positive impact on the aromatic fullness (fruit aroma), in high concentrations it is perceived as green apple smell enriched with a solvent aroma. Acetaldehyde is a direct precursor of ethanol. It is created during the initial stages of fermentation; subsequently its content is reduced. During fermentation, its accumulation in concentrations above the sensibility threshold is possible [15]. No presence of acetaldehyde was detected in the analysed beer.

Diacetyl aromas may also develop after the fermentation ends, at the beer maturing stage. It is a natural product of fermentation and the dominant component of a profile of young beer stored for an insufficiently long period. Predominantly, it results from an insufficient quantity of yeast or presence of a strongly flocculating strain. Its presence in beer may result from a low temperature of fermentation, a process interrupted at an early stage and high pressure in tanks. Presence of bacteria, predominantly from Pediococcus i Lactobacillus strain, is also of importance. Diacetyl adds a butterscotchy, buttery, toffee, creamy or buttermilk flavour to beer [16, 17]. Reduction of the component occurs at a later stage of fermentation and during the maturation. It requires presence of yeast cell reductases. Reduction of the diacetyl facilitates application of the right yeast strain, presence of active cells during after-fermentation and maturation of beer as well as an increase in the number of cells created in the suspension of maturing beer (prevents yeast from accumulating at the bottom of the tank, forced circulation in the cone). An increase in the temperature at the final stage of the fermentation (the diacetyl interruption) also reduces diacetyl concentration in beer. In the analysed beers, diacetyl was found present at the level below $0.05 \mathrm{mg} / \mathrm{l}$ (Table 3).

One of the main groups of compounds synthesised by yeast are higher alcohols (fusel oils). In spite of their negative impact on the taste and aroma of beer, they may be important due to their involvement in the production of esters [18]. They give a plastic, solvent flavour and aroma to beer. In beer containing $50 \%$ of triticale malt (B), the content of isoamyl alcohol was reported at $91.45 \mathrm{mg} / \mathrm{l}$, while in triticale beer $(\mathrm{A})$ and beer from barley malt $(\mathrm{C}$, a lower content of the compound was found (at 89.72 and $98.54 \mathrm{mg} / \mathrm{l}$, respectively) (Table 3). Additionally, aromatic alcohols, e.g., 2-phenylethanol have a negative impact on the beer properties. The component was found at a comparable level in all 
the analysed beers (Table 3). However, sensory properties of beer may benefit from occurrence of some small quantities of higher alcohols. The number of fusel oil produced by yeast is typically in reverse proportion to the content of amino nitrogen in a wort [19].

\section{Conclusions}

The results lead to the conclusions that application of the triticale malt did not disrupt the alcohol fermentation. Beers produced from the triticale malt or with use of a malt mixture were characterised by higher acidity and lower ethyl acetate, butanol and isoamyl alcohol. Other physical parameters were not different from the control samples obtained from the barley malt. However, the worts analysed in the process, produced from the triticale malt demonstrated parameters normative for pale malts. The results of the experiments lead to the conclusion that the triticale malt may be an alternative for barley malt.

\section{Compliance with ethical standards}

Conflict of interest The authors declare that they have no conflict of interest.

Compliance with ethics requirements This article does not contain any studies with human or animal subjects.

Open Access This article is distributed under the terms of the Creative Commons Attribution 4.0 International License (http://creativeco mmons.org/licenses/by/4.0/), which permits unrestricted use, distribution, and reproduction in any medium, provided you give appropriate credit to the original author(s) and the source, provide a link to the Creative Commons license, and indicate if changes were made.

\section{References}

1. Glatthar J, Heinisch JJ, Senn T (2003) The use of unmalted triticale in brewing and its effect on wort and beer quality. J Am Soc Brew Chem 61:182-190

2. Foszczyńska B, Dziuba E (2003) Wpływ słodu pszenżytniego na fizykochemiczne i organoleptyczne właściwości piw. Biotechnologia 2:105-116

3. Błażewicz J, Rytel E (2003) Wpływ produktów hydrolizy enzymatycznej polisacharydów nieskrobiowych na cechy piwa pszenżytniego. Acta Sci Pol Technol Ailm 2:75-82
4. Baca E (1999) Wpływ składu chemicznego wody na proces produkcji i jakości piwa. Przem Ferment i Owocowo-Warzywny 43:35-38

5. Edelen CL, Miller JL, Patino H (1996) Effects of yeast pitch rates on fermentation performance and beer quality. Tech Q Master Brew Assoc Am 1:30-32

6. Pugh TA, Maurer JM, Pringle AT (1997) The impact of wort nitrogen limitation on yeast fermentation performance and diacetyl. Tech Q Master Brew Assoc Am 34:185-189

7. De Rouck G, Van Opstaele F, De Clippeleer J et al (2010) Innovations in industrial beer production and yeast FAN assimilation performance. In: 15th international symposium on scientific and technical advances in malting and brewing, Kraków, pp 191-202

8. Guido LF, Curto A, Boivin P et al (2007) Predicting the organoleptic stability of beer from chemical data using multivariate analysis. Eur Food Res Technol 226:57-62

9. Jurek K, Błażewicz J, Petrów A (2004) Właściwości piw wytwarzanych z dodatkiem produktów przemiału ziarna kukurydzy w warunkach uproszczonej technologii. Żywność Nauk 11:109-118

10. Błażewicz J (1993) Estimation of the usability of triticale malts in brewing industry. Pol J Food Nutr Sci 43:39-45

11. Annemüller G, Manger HJ (2009) Gärung und Reifung des Bieres. VLB, Berlin

12. Procopio S, Qian F, Becker T (2011) Function and regulation of yeast genes involved in higher alcohol and ester metabolism during beverage fermentation. Eur Food Res Technol 233:721-729

13. Verstrepen KJ, Derdelinckx G, Verachtert H, Delvaux FR (2003) Yeast flocculation: what brewers should know. Appl Microbiol Biotechnol 61:197-205

14. Briggs DE, Brookes PA, Stevens R, Boulton CA (2004) Brewing: science and practice. Woodhead Publishing Limited, Cambridge

15. Verbelen PJ, Dekoninck TML, Saerens SMG et al (2009) Impact of pitching rate on yeast fermentation performance and beer flavour. Appl Microbiol Biotechnol 82:155-167

16. Esslinger HM (2009) Handbook of brewing: processes, technology, markets. Wiley, New York

17. Kobayashi K, Kusaka K, Takahashi T, Sato K (2005) Method for the simultaneous assay of diacetyl and acetoin in the presence of $\alpha$-acetolactate: application in determining the kinetic parameters for the decomposition of $\alpha$-acetolactate. J Biosci Bioeng 99:502-507

18. Younis OS, Stewart GG (1998) Sugar uptake and subsequent ester and higher alcohol production by Saccharomyces cerevisiae. J Inst Brew 104:255-264

19. Campbell I (2001) Kształtowanie właściwości sensorycznych piwa przez dobór warunków fermentacji. Przem Ferment i OwocowoWarzywny 8:44-46

Publisher's Note Springer Nature remains neutral with regard to jurisdictional claims in published maps and institutional affiliations. 